a bona fide doubt as to the union's majority. ${ }^{65}$ Furthermore, where the union's majority status has been certified by the Board within the prior year, it cannot be challenged by the employer, regardless of the union's present noncompliance. ${ }^{66}$ Even after expiration of the year, a presumption of continuing majority status exists. ${ }^{67}$ Where an election is held without the participation of the noncomplying union, the ability to prevent rival organizations from obtaining a majority in that contest ${ }^{68}$ will protect the union against certification of others for at least a year. ${ }^{69}$ In a like manner, certification of rivals can be prevented where the noncomplying union has a current contract with the employer..$^{\circ}$

Because of these circumstances, it would appear that the Section is least effective where more powerful unions are involved. This seems anomalous since Congress was presumably most concerned over the threat to commerce and national security inherent in the Communist domination of such unions. ${ }^{7 x}$ In this respect it is significant that the rules worked out in the unfair labor practice cases help prevent loss of strength. On the other hand, such unions, because of their inability to appear on the ballot or achieve a union shop, have suffered losses through the "raiding" tactics of rival complying organizations.72 But even if the union is so weakened that it lacks the economic power to strike for recognition, so long as it maintains a majority the demise of the Andrews rule may discourage the employer from refusing to bargain.

\title{
THE INTERNATIONAL SHOE DOCTRINE AND JURIS- DICTION ON THE BASIS OF ACTS
}

Johns v. Bay State Abrasive Products $C_{0} .^{\mathrm{I}}$ is the first case interpreting and testing the validity of a Maryland statute extending the area of state jurisdiction over foreign corporations. Section $\operatorname{IIg}(\mathrm{d})$ of that statute provides that

${ }^{65}$ John Deere Plow Co. of St. Louis, 82 N.L.R.B. 69 (r949); D. H. Holmes Co., 8r N.L.R.B. 753 (r949). "Whether in a particular case an employer is acting in good or bad faith, is of course a question which of necessity must be determined in the light of all the relevant facts in the case. Among the factors pertinent to a determination of the employer's motive at the time of the refusal to bargain are any unlawful conduct of the employer, the sequence of events, and the lapse of time between the refusal and the unlawful conduct." Artcraft Hosiery Co., 78 N.L.R.B. 333,334 (I948).

${ }^{66}$ Shawnee Milling Co., 82 N.L.R.B. 1266 (r949).

${ }^{6} 7$ Dorsey Trailers, Inc., 80 N.L.R.B. $47^{8}$ (I948).

${ }^{68}$ The noncomplying union is permitted to campaign against its rival. Woodmark Industries, Inc., 80 N.L.R.B. Iro5 (r948).

${ }^{69}$ No election can be held within one year after a valid election has been conducted. Labor

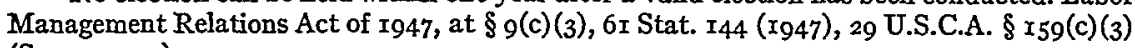
(Supp., r950).

${ }^{20}$ Aluminum Co. of America, 85 N.L.R.B. 9 I 5 (I949). In the absence of a contract, however, the noncomplying union has not even the standing to file objections to the conduct of the election. Times Square Stores Corp., 79 N.L.R.B. 361 (I948).

${ }^{7 x}$ See, e.g., the remarks of Representative Hartley, NLRB, op. cit. supra note 5 at 6 r3.

72 Consult Levinson, op. cit. supra note 54 at ro87 et seq.

$\times 8$ F. Supp. 654 (D.C. Md., I950). 
"[e]very foreign corporation shall be subject to suit in this State by a resident of this State or by a person having a usual place of business in this State on any cause of action arising out of a contract made within this State or liability incurred for acts done within this State, whether or not such foreign corporation is doing or has done business in this State."

An agent of Reed Roller Bit Co. had advised plaintiff's employer that Bay State Abrasive manufactured the best type of grinding wheel to use in conjunction with Reed Roller's pneumatic grinder. The wheel shattered in use, injuring plaintiff, who sued both corporations under Maryland's Workmen's Compensation Act. Both defendants were served by a form of substituted service upon the Maryland State Tax Commission, which in turn notified defendants by registered mail. ${ }^{3}$ The case was removed to the United States District Court on the ground of diversity of citizenship, and defendants moved to dismiss the action, asserting that the court had no jurisdiction since defendants were both foreign corporations not "doing business" within the state. The court ruled only upon defendants' motions, and finding that neither defendant was "doing business" in the state within the meaning of Article $23, \S \operatorname{IIg}(\mathrm{c})^{4}$ which authorized jurisdiction on that basis, the court was forced to decide whether or not the statute quoted gave jurisdiction.

A reasonable construction of the statute in question would indicate that it seeks to establish jurisdiction over foreign corporations for certain isolated acts. In an attempt to define these acts the court stated: "While application of ... section IIg(d) when literally applied in some cases might infringe the due process clause, I hesitate to reach the conclusion that there are not other situations in which its application may be consistent with due process."s These "situations" were to be determined consistent with the approach in International Shoe Co. v. Washington. ${ }^{6}$ Quoting from the opinion in that case the court said that "the foreign corporation's activities must be such as to 'establish sufficient contacts or ties with the state of the forum to make it reasonable and just according to our traditional conception of fair play and substantial justice to permit the state to enforce the obligations which appellant has incurred there." "7

It was held to be irrelevant that both corporations completed about $\$$ I5,000 worth of sales in Maryland per year, and that Reed Roller's agent, while not authorized to do more than solicit orders, had been regularly accepting orders

$=$ Md. Code Ann. (Flack, I939) art. 23, $\S$ II9(d) (Supp. I947) (emphasis added). For favorable comment on $\S \mathrm{rrg}(\mathrm{d})$ see Reiblich, Jurisdiction of Maryland Courts over Foreign Corporations under the Act of 1937,3 Md. L. Rev. 35 (1938).

${ }_{3} \mathrm{Md}$. Code Ann. (Flack, r939) art. 23, $\S \operatorname{Irr}(\mathrm{d})$ (Supp., r947) provides for such service on corporations subject to the state's jurisdiction under § II9.

4 Md. Code Ann. (Flack, r939) (Supp., I947).

5 Johns v. Bay State Abrasive Products Co., 89 F. Supp. 654, 66I (D.C. Md., I950).

${ }^{6} 326$ U.S. 3 Io (1945).

7 Johns v. Bay State Abrasive Products Co., 89 F. Supp. 654, 662 (D.C. Md., 1950). 
for at least a year and giving advice to prospective customers in Maryland as to the utility and sufficiency of Reed Roller's product. But this agent had, in Maryland, recommended to plaintiff's employer that he purchase a Reed Roller Grinder and further, that he use a grinding wheel manufactured by Bay State Abrasive Co., which wheel by shattering injured plaintiff. Although plaintiff's employer actually purchased both grinder and wheel from an independent supplier, the acts of Reed Roller's agent in giving advice were judged by the court to be within the ambit of the Maryland statute, and its application did not violate the due process clause of the Constitution of the United States. The court found that Bay State had made no contract, and had no transaction within Maryland in relation to the alleged liability, and $\S \mathrm{IIg}(\mathrm{d})$ was therefore inapplicable by its terms. Bay State's motion to dismiss was granted, and Reed Roller's overruled.

It does not seem unreasonable to subject foreign corporations to the jurisdiction envisaged in the Maryland statute, nor does there seem to be reason for exempting natural persons from similar jurisdiction if attempted under appropriate legislation. It was once thought that states could not obtain jurisdiction over nonresident natural persons by substituted service on the basis of their having "done business" in the state. The Supreme Court said in Flexner v. Farson ${ }^{8}$ that the fictional "consent" theory could not be applied to individuals, since the state had no power to exclude individuals from doing business in the state, as it had with respect to foreign corporations. But in Davidson v. Doherty, 9 the Iowa Supreme Court upheld an Iowa statute giving jurisdiction over a nonresident individual "doing business" within the state, basing its opinion largely on the ground that a nonresident individual was subject to "reasonable regulation." The United States Supreme Court upheld Iowa's statute providing for substituted service in the similar case of Doherty v, Goodman, $^{\text {IO }}$ but emphasized the fact that the nonresident defendant was in a business particularly subject to state regulation, the selling of investment securities. Although there have been no Supreme Court cases directly on this point since Doherty v. Goodman, states have continued to subject to their jurisdiction defendants not resident or present, on the basis of having "done business" within state boundaries. II Mississippi and Arkansas have statutes which not only seek to give jurisdiction over individuals not resident or present within the state on the basis of "doing business," but look toward jurisdiction over persons for individual acts committed within the state. ${ }^{\text {Iz }}$

8248 U.S. 248 (I9I9).

92 I4 Towa 529, 24 I N.W. 700 (1932).

10 294 U.S. 623 (x935).

Ir Sugg v. Hendrix, I42 F. 2d 740 (C.A. 5th, I944); Gillioz v. Kincannon, 213 Ark. roro, 2I4 S.W. 2d 2I2 (I948); Davidson v. Doherty, 2I4 Iowa 529, 24I N.W. 700 (I932); Melvin Pine \& Co. v. McConnell, 273 App. Div. 218, 76 N.Y.S. 2d 279 (Ist Dep't, r948), aff'd 298 N.Y. 27, 80 N.E. 2d I37 (r948); Stoner v. Higginson, 3I6 Pa. 48I, I75 Atl. 527 (I934).

I2 Miss. Code Ann. (r942) § I437; Ark. Stat. Ann. (I947) tit. 27, § 340. 
It is suggested that the constitutional doctrine of the International Shoe ${ }^{x_{3}}$ case in effect overrules Flexner v. Farson, ${ }^{\mathrm{I4}}$ and is applicable to and would uphold not only statutes intending to give jurisdiction over natural persons not resident or present in the state on the basis of "doing business," but also statutes granting jurisdiction over such persons for individual acts within the state. The language of the International Shoe case is not restricted to foreign corporations, and as applied in the Johns case satisfies the safeguards necessary to due process.

Jurisdiction similar to that in the Maryland statute under consideration has been upheld in regard to both foreign corporations and natural persons. Even before jurisdiction was extended over nonresident natural persons "doing business" in a state, jurisdiction on the basis of doing a single, particular act was upheld in connection with the nonresident motorist statutes. ${ }^{15}$ These statutes have been held to apply to foreign corporations. ${ }^{16}$ Pennsylvania has a statute which provides for personal service by registered mail on nonresidents who have certain connections with real property located within the state, abutting streets or sidewalks, in any civil action brought in Pennsylvania in which such real property is involved. ${ }^{77}$ Under this statute successful plaintiffs would, of course, obtain judgments in personam. In Dubin v. Philadelphia ${ }^{88}$ a Pennsylvania court upheld the constitutionality of the statute in an action against a resident of New Jersey.

English courts, at their discretion, may assert jurisdiction over nonresidents on the basis of the commission of certain specified acts, through the medium of service outside of the jurisdiction. In the Common Law Procedure Act (I852) ${ }^{x 9}$ provision was made for service of the notice of writ of summons abroad, on the basis of certain acts. However, this act was construed not to pertain to foreign corporations. ${ }^{20}$ These provisions were superseded by the Rules of the Supreme Court, ${ }^{21}$ made under the authority of the Judicature Act (1875);22 and the new Rules were held to apply not only to individuals not present or resident in England, but also to foreign corporations in Scott v. Royal Wax Candle Co., in $1876 .{ }^{23}$

Currently, foreign corporations as well as individuals not present or resident

${ }_{3}$ International Shoe Co. v. Washington, 326 U.S. 3 I0 (I945).

${ }^{14} 248$ U.S. 248 (Igrg).

15 Wuchter v. Pizzutti, 276 U.S. I3 (I928); Hess v. Pawloski, 274 U.S. $35^{2}$ (I927).

${ }^{16}$ Martin v. Fishbach Trucking Co., I83 F. $2 d 53$ (C.A. Ist, 1950). Jones v. Pebler, 37 I Ill. 309, 20 N.E. 2d 592 (1939); Bischoff v. Schnepp, I39 N.Y. Misc. 293, 249 N.Y. Supp. 49 (N.Y. City Ct., 1930).

${ }_{17} \mathrm{~Pa}$. Stat. Ann. (I93r) tit. I2 $\$ 33$ I.

${ }^{88} 34$ Pa. D. \& C. 6I (C.P., I938), noted in 87 U. of Pa. L. Rev. IIg (I938).

${ }^{19}{ }_{15} \& 16$ Vict., c. 76 (1852).

20 Ingate v. Le Commisione Del Lloyd Austrian, [1858] 4 C.B. (N.S.) 705.

${ }^{2 x}$ Rules of the Supreme Court, Order XI, rule I (I875).

${ }_{22} 38$ \& 39 Vict., c. 77 ( 1875$)$.

${ }^{23}$ [1876] I Q.B.D. 404, 34 L.T. 683. 
in England may be served abroad when, inter alia, the action is brought upon a contract if (i) made within the jurisdiction, or (ii) made by or through an agent trading or residing within the jurisdiction on behalf of a principal trading or residing out of the jurisdiction, or (iii) by its terms to be governed by English law, or (iv) is brought in respect of a breach committed within the jurisdiction, of a contract wherever made.24 Additional situations in which such jurisdiction may be asserted include actions founded upon a tort committed within the jurisdiction, ${ }^{25}$ or attempts to enjoin acts to be committed within the jurisdiction, ${ }^{26}$ or for the inclusion of any person out of the jurisdiction, who is a necessary or proper party to an action properly brought against some person duly served within the jurisdiction. ${ }^{27}$ To avoid working hardship upon defendants in .these cases, the defense of forum non conveniens is available to persons attempting to avoid the jurisdiction of the English courts. ${ }^{28}$

In generalizing upon the English law on this subject, one writer has aptly said: "A general right to compel foreign defendants to appear in England is not asserted; so long as foreigners keep themselves free from English transactions, they are not subject to the power of English courts; but it is regarded as fair and reasonable to subject foreigners to substituted service and suit in the English courts until their voluntary transactions affecting England are completed." 29

24 Rule of the Supreme Court, Order XI, rule I(e) (I883), I Annual Practise roo (1949). For detailed explication see Dicey, Conflict of Laws $\times 83$ et seq. (6th ed., Morris, x949). Domiciliaries of Scotland and Ireland are in some cases exempt from these general provisions. Service in England on corporations which have not registered the names of agents authorized to receive service of summons, in causes not within the ambit of the rules enabling extraterritorial service, hinges upon "residence" in Great Britain. In Dunlop Pneumatic Tyre Co. v. Actien-Gesellschaft, [I902] I K.B. $34^{2}$ (C.A.), it was held that service upon defendant corporation in England was valid, since defendant conducted a material part of its business (viz., sales), at a fixed place of business (viz., a stall at the Crystal Palace), for a substantial period of time (viz., nine days). Consult also Saccharin Corp. v. Chemische Fabrik von Heyden, [I9Ir] 2 K.B. ${ }_{5}$ I6 (C.A.); Actiesselkabet Damskib "Hercules" v. Grand Trunk Pacific Ry. Co., [Igr2] I K.B. 222 (C.A.). For further rules of jurisdiction over foreign defendants see the Companies Act, II \& I2 Geo. VI, c. $38, \S \S 406-$ I6 (x948) and the Carriage by Air Act, 22 \& 23 Geo. V, c. 36 (1932).

${ }_{25}$ Rules of the Supreme Court, Order XI, rule I(ee), I Annual Practise ror (I949).

${ }^{26} \mathrm{Ibid}$., rule I(f). A recent United States example of the use of this basis for jurisdiction was affirmed by the Supreme Court in Travelers Health Ass'n v. Virginia, 339 U.S. 643 (I950), commented upon in I7 Univ. Chi. L. Rev. 382 (1950) after decision by the Virginia Court of Appeals, I88 Va. 877 , 5 I S.E. $2 d 263$ (r949). Travelers Health Ass'n, a nonprofit association incorporated in Nebraska with sole office in Omaha, carried on a health insurance business by mail order. Defendants were given notice by registered mail of the State Corporation Commission's order to cease and desist further solicitations or sales of certificates to Virginia residents "through medium of any advertisement from within or from without the state, and/or through the mails or otherwise, by intra- or interstate communication ... unless and until" it had received authority in accordance with the state Blue Sky law. 339 U.S. 643,646 (r950).

${ }^{27}$ Rules of the Supreme Court, Order XI, rule $I(\mathrm{~g})$ ( $\left.\mathrm{I} 88_{3}\right)$.

${ }^{28}$ Logan v. Bank of Scotland, [I9०6] I K.B. x4I (C.A.); followed in Egbert v. Short, [I9०7] 2 Ch. 205 .

29 Culp, Process in Actions Against Non-Residents Doing Business within a State, 32 Mich. L. Rev. 909, 926-27 (1934). 
Similar rules are in effect in all other jurisdictions of the British Empire and Commonwealth.

Roman law, under the doctrine of forum contractus, allowed a nonresident to be sued where he had established a temporary seat of business and in some cases, where he had contracted but one obligation. ${ }^{30}$ There was also a special jurisdiction over persons based upon a delict committed within the jurisdiction, the forum delicti. ${ }^{3 x}$ Forum contractus and fortun delicti have received wide recognition in civil law countries. ${ }^{32}$

The disparity in the law concerning jurisdiction between civil law countries and the United States may, perhaps, be adequately explained by the different degrees to which they have been influenced by Roman law. But this does not explain why England recognizes jurisdiction over foreign individuals and corporations on the basis of the doing of certain acts connected with the jurisdiction, while American courts recognize such basis for jurisdiction in only a few specific situations. One hypothesis which might be advanced is that for British subjects (except in Commonwealth nations) a foreign corporation means one incorporated in a foreign country, and the British courts and House of Commons did not wish to force residents of Britain to prosecute actions against nonresidents in courts where the law, procedure and language were unfamiliar, and where it seemed reasonable to force nonresidents to defend in England because the transaction sued upon was connected with England. American plaintiffs would not have this difficulty in so great a degree, so that the need for a similar basis of jurisdiction is not so pressing. Perhaps unexpressed notions about the need for increased manufactures in the United States were responsible for the courts' hesitancy to subject to jurisdiction persons not resident or present, or corporations away from their "homes," in states where they did not carry on a really significant portion of their business activity. The opposite course, if adopted, might conceivably have slowed the growth of business enterprise by increasing liability.

There are many policy matters to be considered in proposing that the law of jurisdiction in the United States move in the direction shown by foreign law. The doctrine of reciprocity has some application to this problem. If nonresident corporations or individuals voluntarily come into states and engage in transactions with residents, the nonresident has the privilege of using that state's courts to enforce whatever rights accrue to it.

States have a legitimate interest in protecting their citizens and administering their laws. Perhaps this can best be accomplished if a state is given jurisdiction over causes arising out of acts committed within or closely connected with its territory. The opportunity for a resident of a state to prosecute within it actions in personam against a nonresident where actual notice may easily be given, seems to be neither less important nor more burdensome to the defendant

\footnotetext{
30 Westlake, Private International Law 229 (6th ed., Bentwich, I922).

${ }^{3 x}$ Tbid., at 230 .

32 Ibid., at 238 .
} 
than the adjudication of interests in tangible goods, wherein states may cut off nonresidents' interests with no actual notification. ${ }^{33}$ Furthermore, witnesses to transactions between nonresidents and residents are more likely to live in the state which the nonresident entered.

It would be difficult for corporations or individuals to defend in distant jurisdictions where they might have no agents, office, or other organization. But if the Maryland type of jurisdiction were to be sustained, the courts would still retain their discretionary power on pleas of forum non conveniens to prevent hardship on nonresident defendants. ${ }^{34}$ This basis for jurisdiction over nonresidents might increase their costs of defense, for it can be foreseen that a goodsized, active corporation or other business would possibly be forced to defend many claims in various jurisdictions. The hardship would certainly not be greater, however, than that which arises from the well-established right to sue a corporation doing business in the forum upon causes of action which are totally unconnected with it. In addition, it seems reasonable to require the public to share the social cost ${ }^{35}$ of enterprise by paying higher prices for the goods and services produced by businesses operating across state boundaries. ${ }^{36}$

This system of jurisdiction would leave unsolved the problem of protecting nonresidents from plaintiffs who obtain default judgments on unfounded claims, which the nonresident considers not worthy of defending. It does not resolve the difficulty of the successful plaintiff who finds that the defendant has no property within the jurisdiction. But it probably is simpler and less expensive for such plaintiffs to enforce judgments in another jurisdiction than it is to travel to other jurisdictions to try their cases upon the merits.

In view of the large volume of enterprise carried on across state boundaries the future may see increasing state jurisdiction over nonresident defendants under statutes similar to the Maryland statute construed in Johns v. Bay State Abrasive Products Co., consistent, of course, with the constitutional doctrine set out in International Shoe Co. v. Washington. ${ }^{37}$

\section{ACCESS PROBLEMS IN STRATIFIED ESTATES}

Division of the earth's subsurface into separate strata of ownership has raised special problems in the law of property. One type of controversy results

33 Anderson National Bank v. Luckett, 32I U.S. 233 (x944); Security Savings Bank v. California, 263 U.S. 282 (I923).

34 In Leet v. Union Pacific R. Co., 25 Cal. 2d 605, I55 P. 2d 42 (I944), cert. denied 325 U.S. 866 (I945), the court described forum non conveniens as being an equitable rule embracing the discretionary power of a court to decline to exercise jurisdiction which it has over a cause of action where it believes that the action may be more appropriately and justly tried elsewhere.

${ }^{35}$ Social cost being the cost of adjudicating claims between residents and enterprises resident in distant jurisdictions.

${ }^{36}$ Adopting in part the rationale given by Justice Douglas for the existence in our law of vicarious liability without fault in his article Vicarious Liability and Administration of Risk, 38 Yale L.J. 584 (I929).

${ }^{37} 326$ U.S. 3 I0 (I945). 